\title{
YELLOW FEVER PREVENTION STRATEGIES AWARENESS AMONG HIV-INFECTED PATIENTS IN SÃO PAULO, BRAZIL
}

\author{
Vivian Iida AVELINO-SILVA(1), Hilario Sousa FRANCELINO(2) \& Esper Georges KALLÁS(1,2)
}

\begin{abstract}
SUMMARY
Introduction: Vaccination is the main preventive strategy against Yellow Fever (YF), which is a public health concern in Brazil. However, HIV-infected patients might have insufficient knowledge regarding YF, YF prevention, and vaccines in general. Methods: In this questionnaire-based study, data from 158 HIV-infected individuals were addressed in three distinct outpatient clinics in São Paulo. Information was collected on demographic and clinical characteristics, as well as patients' knowledge of vaccines, YF and YF preventive strategies. In addition, individual YF vaccine recommendations and vaccine status were investigated. Results: Although most participants adequately ascertain the vaccine as the main prevention strategy against $\mathrm{YF}$, few participants were aware of the severity and lack of specific treatment for YF. Discrepancy in YF vaccine (patients who should have taken the vaccine, but did not) was observed in $18.8 \%$ of participants. Conclusion: YF is an important and preventable public health concern, and these results demonstrate that more information is necessary for the HIV-infected population.
\end{abstract}

KEYWORDS: HIV; AIDS; Yellow Fever; Vaccine; Questionnaire.

\section{INTRODUCTION}

Yellow fever (YF) is a public health concern in several Latin American and African countries. Vaccination is the main preventive strategy for this highly lethal disease, for which a specific treatment is lacking ${ }^{6}$.

In Brazil, the areas with recommendation for YF vaccine have been subjected to extension during the last decades after new YF epidemics and epizooties were documented in regions previously considered as out of risk ${ }^{1-2}$. Nevertheless, the population's awareness on the disease, as well as the prevention strategies, is probably far from ideal.

HIV-infected patients are supported by the Brazilian public health system, for inpatient and outpatient care, antiretroviral therapy, and vaccines. A very small percentage of HIV-infected patients attend private medical offices. Despite regular access for treatment and health information during their clinical follow up, there is a hypothesis that HIV-infected patients have insufficient knowledge regarding YF, YF preventive strategies, and vaccines in general.

To address this issue, a self-completion questionnaire was applied to 158 HIV-infected patients regularly monitored in three outpatient clinics in São Paulo, Brazil.

\section{METHODS}

A cross sectional study was performed from March to November 2013, and included HIV-infected patients regularly monitored in three outpatient clinics in São Paulo, Brazil: one large public outpatient clinic (Group 1), one HIV clinical research cohort (Group 2), and one private clinic (Group 3). All participants provided an informed consent, and participants' identities were kept confidential. The study was approved by the Ethics Committee of the University of São Paulo Medical School.

Self-completion questionnaires were applied in the clinic's waiting area, either before or immediately after the medical appointment. Data were collected regarding demographic and clinical characteristics, last season's Influenza vaccination history, and patients' knowledge of vaccines, YF and YF preventive strategies. In addition, individual YF vaccine status was investigated. All data were collected in the form of closed questions.

The demographic and clinical characteristics referred by the three groups of patients were compared by Pearson's chi-square test or by Fisher's two-sided exact test. The age between the groups was compared using the Kruskal-Wallis-test. The Bonferroni correction was calculated for each pairwise comparison performed. The $95 \%$ confidence intervals for the percentage of binomial variables were calculated using the exact binomial method. All statistical tests used a significance level of 0.05

(1) Department of Infectious Diseases, University of São Paulo Medical School, São Paulo, SP, Brazil.

(2) Discipline of Clinical Immunology and Allergy, University of Sao Paulo Medical School, São Paulo, SP, Brazil.

Correspondence to: Vivian Iida Avelino-Silva. E-mail:viviansilva87@gmail.com 
and were performed using STATA 13.0 (StataCorp. College Station, TX: StataCorp LP.)

\section{RESULTS}

The study enrolled 91 participants in Group 1, 37 participants in Group 2 and 30 participants in Group 3, for an overall population of 158 HIV-infected patients.

Most participants were male (77.9\%), with a median age of 44 years. Group 1 was significantly older than Groups 2 and 3, while Group 3 had a higher proportion of white ethnicity when compared to Group 1, and a higher proportion of graduate participants when compared to Groups 1 and 2.

According to the age distribution, chronic conditions other than HIV were found more frequently in Group 1 .
Most participants in the three groups reported that children, healthy adults, adults with chronic conditions and elderly are populations to whom vaccines are important. A significantly smaller proportion of participants in Group 3 reported receiving a medical recommendation for vaccines during follow up, when compared to Group 1. In addition, fewer patients in Group 3 reported receiving the flu vaccine in the last season when compared to Group 1.

Regarding YF knowledge, although most participants adequately identify mosquitoes as YF transmission agents and vaccine as the main prevention strategy, in all three groups few participants are aware of the severity and lack of specific treatment for YF.

A higher proportion of participants in Group 3 reported traveling to or living in YF endemic areas, and accordingly Group 3 had a higher proportion of vaccinated participants. Discrepancy in YF vaccine (patients who should have taken the vaccine, but did not) was observed in $18.8 \%$ of participants (CI 95\% $=13.0-25.9)$.

Table 1

Demographic characteristics of participants and survey results

\begin{tabular}{|c|c|c|c|c|}
\hline & $\begin{array}{c}\text { Total } \\
(\mathrm{N}=158)\end{array}$ & $\begin{array}{c}\text { Group } 1 \\
(\mathrm{~N}=91)\end{array}$ & $\begin{array}{c}\text { Group } 2 \\
(\mathrm{~N}=37)\end{array}$ & $\begin{array}{c}\text { Group } 3 \\
(\mathrm{~N}=30)\end{array}$ \\
\hline Age (median, p25-75) & $44(36-52)$ & 49 & 36 & 37 \\
\hline Male $(\%(\mathrm{~N}))$ & $77.8(123)$ & $73.6(67)$ & $83.8(31)$ & $83.3(25)$ \\
\hline $\begin{array}{l}\text { Ethnicity }(\%(\mathrm{~N})) \\
\text { White } \\
\text { Black } \\
\text { Mulatto } \\
\text { Other/not reported }\end{array}$ & $\begin{array}{l}60.8(96) \\
8.9(14) \\
27.9(44) \\
2.5(4)\end{array}$ & $\begin{array}{l}53.8(49) \\
13.2(12) \\
29.7(27) \\
3.3(3)\end{array}$ & $\begin{array}{c}59.5(22) \\
5.4(2) \\
35.1(13) \\
\quad-\end{array}$ & $\begin{array}{c}83.3(25) \\
- \\
13.3(4) \\
3.3(1)\end{array}$ \\
\hline $\begin{array}{l}\text { Education level }(\%(\mathrm{~N})) \\
\text { Elementary } \\
\text { Middle school } \\
\text { High school } \\
\text { College/Graduate } \\
\text { Not informed }\end{array}$ & $\begin{array}{c}3.2(5) \\
12.7(20) \\
33.5(53) \\
50(79 ; 42-58) \\
0.6(1)\end{array}$ & $\begin{array}{c}4.4(4) \\
19.8(18) \\
37.4(34) \\
37.4(34) \\
1.1(1)\end{array}$ & $\begin{array}{c}- \\
5.4(2) \\
43.2(16) \\
51.4(19) \\
-\end{array}$ & $\begin{array}{c}3.3(1) \\
- \\
10(3) \\
86.7(26) \\
-\end{array}$ \\
\hline Chronic conditions other than HIV (\% (N)) & $52.9(83)$ & $65.9(60)$ & $33.3(12)$ & $36.7(11)$ \\
\hline $\begin{array}{l}\text { To which groups are vaccine important? }(\%(\mathrm{~N})) \\
\text { Children } \\
\text { Healthy adults } \\
\text { Adults c. conditions } \\
\text { Elderly } \\
\text { All the above }\end{array}$ & $\begin{array}{l}88.0(139) \\
82.9(131) \\
73.4(116) \\
82.9(131) \\
63.3(100)\end{array}$ & $\begin{array}{l}90.1(82) \\
80.2(73) \\
68.1(62) \\
80.2(73) \\
59.3(54)\end{array}$ & $\begin{array}{l}78.4(29) \\
89.2(33) \\
75.7(28) \\
81.1(30) \\
64.9(24)\end{array}$ & $\begin{array}{l}93.3(28) \\
83.3(25) \\
86.7(26) \\
93.3(28) \\
73.3(22)\end{array}$ \\
\hline $\begin{array}{l}\text { Personal physician recommended vaccines during follow up (\% (N)) } \\
\text { Received last season's Flu vaccine }\end{array}$ & $\begin{array}{l}81.6(129) \\
81.0(128)\end{array}$ & $\begin{array}{l}89.0(81) \\
89.0(81)\end{array}$ & $\begin{array}{l}83.8(31) \\
81.1(30)\end{array}$ & $\begin{array}{l}56.7(17) \\
56.7(17)\end{array}$ \\
\hline $\begin{array}{l}\text { Knowledge in YF }(\%(\mathrm{~N})) \\
\text { Correctly identifies mosquitoes as transmission route } \\
\text { Correctly identifies YF as potentially severe disease, with no } \\
\text { specific treatment } \\
\text { Correctly identifies vaccine as YF prevention strategy } \\
\text { Travels to YF endemic areas } \\
\text { Past YF vaccine } \\
\text { Travels to YF endemic areas but never received YF vaccine }\end{array}$ & $\begin{array}{l}82.2(129) \\
14.6(23) \\
86.0(135) \\
44.6(70) \\
27.4(43) \\
18.8(29)\end{array}$ & $\begin{array}{l}76.9(70) \\
15.4(14) \\
81.3(74) \\
28.6(26) \\
15.4(14) \\
19.3(17)\end{array}$ & $\begin{array}{l}86.1(31) \\
11.1(4) \\
94.4(34) \\
66.7(24) \\
25(9) \\
22.2(8)\end{array}$ & $\begin{array}{c}93.3(28) \\
16.7(5) \\
\\
90(27) \\
66.7(20) \\
66.7(20) \\
13.3(4)\end{array}$ \\
\hline
\end{tabular}




\section{DISCUSSION}

Brazilian state policies define selected regions in which the vaccine is recommended, either for those living or traveling to these locations. In the last decades, massive vaccination campaigns have followed the expansions in the YF vaccine recommendation area ${ }^{1,2}$. Nevertheless, this study found a large percentage of HIV-infected patients who are unaware of YF severity and lack of specific treatment. Furthermore, a significant proportion of participants should have been vaccinated, but remains unprotected.

Although several countries keep border vigilance systems for YF vaccine adequacy, vigilance for persons already inside the country's frontiers are frequently lacking. Thus, non-immune individuals may enter the vaccine recommendation regions, posing a significant individual risk, as well as a risk for YF urbanization ${ }^{5}$.

Several previous studies have addressed knowledge, attitudes and practices (KAP) of travelers towards travel-related infectious diseases in airport surveys, also demonstrating important drawbacks in travelers' KAP, which emphasize the need for better knowledge among travelers regarding preventable diseases ${ }^{3,8,9}$.

Although income was not investigated in this survey, it is likely due to better financial conditions that more patients in Group 3 reported traveling to YF risk areas and, accordingly, more participants in this Group had been vaccinated against YF, with only $13 \%$ reporting traveling to endemic areas without previous vaccination. Group 3 had less patients vaccinated against Influenza in the last season, and a smaller proportion of patients in Group 3 had received recommendation for vaccines during follow up. One possible explanation is related to the existence of a vaccination unit inside the clinic attended by Groups 1 and 2, but not by Group 3 .

A general notion, possibly more consistent among individuals with a lower level of education, states that vaccines are beneficial only in extreme ages - young children and the elderly - and unnecessary in adults. This hypothesis has been tested in this study. These results may be biased due to the fact that this population of HIV-infected patients is different to the average adult population, either due to a higher level of education, or to the information delivered by the health care providers during clinical follow up. In addition, adult HIV-infected patients have specific vaccine recommendations, which might also increase awareness regarding vaccines in this population.

Risk perception is a complex issue, and previous studies have addressed the importance of effective communication on the risk of preventable diseases, as opposed to the risk of vaccination and other social, cultural and economic factors that may influence vaccination decisions $^{4,7}$.

Anti-vaccination movements might also have an influence on vaccine compliance, but they do not seem to bring a particular impact on YF vaccine. On the other hand, reports on severe adverse events of the YF vaccine, and more specifically the YF vaccine-associated viscerotropic disease, have been described with increasing frequency. Even though the increasing frequency may be, at least, partially attributed to surveillance, the fear of such adverse events might have diminished vaccine uptake by travelers and residents in risky areas, or even health care providers' recommendations for the vaccine; however, this hypothesis needs further investigation.

It is believed that these results are essential for this group of patients. First, they point out the main deficiencies in the knowledge of the HIVinfected population, and provide hints for education strategies. Second, they are indicators of the quality of HIV care in this setting. This is increasingly important in the Highly Active Antiretroviral Therapy era, when opportunistic conditions become rarer, and focus has changed to prevention strategies and primary care management. Third, the presence of unvaccinated participants who should have taken the vaccine in this group points to a deficiency in vaccination strategies.

This study has some limitations. The sample size was not very large and not randomly attained. Furthermore, selected outpatient clinics may not adequately represent the overall HIV-infected population. However, the results revealed important information on YF and YF vaccine awareness that may guide future actions to spread the knowledge of these issues and other preventable infectious diseases with immunogens, especially to those travelling to infectious disease-endemic areas.

In conclusion, YF is an important and preventable public health concern, and these results demonstrate that more information is necessary for the HIV-infected population.

\section{RESUMO}

\section{Nível de conhecimento sobre estratégias de prevenção contra febre amarela entre pessoas que vivem com HIV em São Paulo, Brasil}

A vacinação é a principal forma de prevenção contra a Febre Amarela (FA), doença de importância em saúde pública no Brasil. Entretanto, pessoas que vivem com HIV possivelmente possuem conhecimentos insuficientes a respeito da FA, suas formas de prevenção e também sobre vacinas de modo geral. Métodos: Neste estudo baseado em questionários de autopreenchimento, avaliamos dados de 158 pacientes infectados por HIV atendidos em três diferentes serviços ambulatoriais do Município de São Paulo. Foram coletados dados demográficos, clínicos, e dados relacionados ao grau de conhecimento a respeito de vacinas, da FA e de suas formas de prevenção. Além disso, avaliamos individualmente a indicação e antecedente de vacinação contra FA. Resultados: Embora a maioria dos participantes tenha identificado corretamente que a vacina é a principal forma de prevenção da FA, poucos tinham conhecimento a respeito da gravidade clínica e ausência de tratamento específico da doença. Discrepância na vacinação (caracterizada quando o participante deveria ter recebido a vacina, mas não a recebeu) foi observada em $18,8 \%$ dos casos. Conclusão: A FA é importante agravo em saúde pública, passível de prevenção, e nossos resultados demonstram que são necessárias mais ações de educação voltadas à população de pessoas que vivem com HIV.

\section{ACKNOWLEDGEMENTS}

The authors would like to thank Karina Takesaki Miyaji, Ana Marli Sartori and Marta Heloisa Lopes for reviewing the original survey and providing useful suggestions. The authors would also like to thank Tamara Newman Lobato Sousa, Jessica Fernandes Ramos and Fabiana Siroma for helping the application of the questionnaires. This study was supported by CAPES (Ministério da Educação - Brazil). 


\section{AUTHORS' CONTRIBUTION}

VIAS devised the study, participated in the collection of clinical data, study design and manuscript writing; HSF participated in the collection of clinical data and manuscript revision; EGK coordinated the study and helped to draft the manuscript. All of the authors read and approved the final manuscript.

\section{REFERENCES}

1. Brasil. Ministério da Saúde. Secretaria de Vigilância em Saúde. Emergências em saúde pública de importância nacional (ESPIN) de febre amarela silvestre em São Paulo e no Rio Grande do Sul e a situação epidemiológica atual no Brasil (2008/2009). Brasília: Ministério da Saúde; 2009.

2. Brasil. Ministério da Saúde. Secretaria de Vigilância em Saúde. Situação da febre amarela silvestre no Brasil, 2007 e 2008. Brasília: Ministério da Saúde; 2008.

3. Hamer DH, Connor BA. Travel health knowledge, attitudes and practices among United States travelers. J Travel Med. 2004;11:23-6.
4. Larson H, Brocard Paterson P, Erondu N. The globalization of risk and risk perception: why we need a new model of risk communication for vaccines. Drug Saf. 2012;35:1053-9.

5. Lima JTF. Risco de urbanização da febre amarela no Brasil. Cad Saúde Pública. 1985;1:377-84.

6. Monath TP. Yellow fever: an update. Lancet Infect Dis. 2001;1:11-20.

7. Reyna VF. Risk perception and communication in vaccination decisions: a fuzzy-trace theory approach. Vaccine. 2012;30:3790-7.

8. Toovey S, Jamieson A, Holloway M. Travelers' knowledge, attitudes and practices on the prevention of infectious diseases: results from a study at Johannesburg International Airport. J Travel Med. 2004;11:16-22.

9. Van Herck K, Van Damme P, Castelli F, Zuckerman J, Nothdurft H, Dahlgren AL, et al. Knowledge, attitudes and practices in travel-related infectious diseases: the European airport survey. J Travel Med. 2004;11:3-8.

Received: 12 November 2013

Accepted: 14 March 2014 